Journal of Environmental Sciences (JES)

Faculty of Graduate Studies and Environmental Research, Ain Shams University

Mansour et al.

\title{
UTILIZATION OF WHEY CHEESE AND OAT WHOLE- GRAIN TO CONTROLLING WEIGHT GAIN IN RATS FED ON HIGH FAT DIET
}

\author{
Wael M. Mansour ${ }^{(1)}$; Mohammad A. El-Nawawy ${ }^{(2)}$ \\ Wageeh A. El-Malky ${ }^{(1)}$ and Ihab S. Ashoush ${ }^{(2)}$ \\ 1) National Organization for Drug Control and Research (NODCAR) \\ 2)Faculty of Agriculture, Ain Shams University
}

\begin{abstract}
Nowadays foods are not purposed to only fulfill hunger and to supply vital nutrients for humans but, also to prohibit nutrition-related diseases and improve physical and mental well-being of the consumers. In this respect, functional foods play distinguished role. Therefore, the aim of this study was to examine the effect of addition of whey cheese and oat whole grain powder in biscuits and crackers by different formulae to produce low calorie biscuits and crackers, and to evaluate their effectiveness on weight gain and lipid profiles in rats fed on a high-fat diet. Feeding rats on different biscuits and crackers formulae recorded reduced body weight gain, adipocyte histological alteration. Feeding rats led to a significant reduction in the levels of LDL and total cholesterol and an improvement in the HDL levels.

In conclusion, consumption of whey cheese and oat whole-grain in form of low calorie biscuits and crackers formula reduced the adipocytes histological changes, resulting in reduction of the body weight of the rats.
\end{abstract}

Keywords: Whey Cheese, Oat, Weight Gain, Lipid Profile, Rats.

\section{INTRODUCTION}

Overweight is a condition due to excess energy intake that stored in the form of fat in adipose tissues to store fat in the human body. The adipose tissue increases either in cell size or in cell number that may negatively affect 
Journal of Environmental Sciences (JES)

Faculty of Graduate Studies and Environmental Research, Ain Shams University

Mansour et al.

other organs like the heart, pancreas and liver. Nowadays, overweight is considered as a medical health problem. The risk of becoming overweight or obese is affected by different factors, including genetics, inactive lifestyle، consumption of high fat or carbohydrates diets, certain medications, social and economic issues and lack of sleep. Generally, overweight and obesity are linked to health problems such as cardiovascular disease، hypertension, diabetes and colon cancers (ASN, 1998; Hruby and Hu, 2015; Stenkula and Erlanson-Albertsson, 2018).

Whey cheese is a liquid obtained after the precipitation of milk casein in the cheese making process. The production of whey cheeses is based on the denaturation and coagulation of the water soluble milk proteins present in the whey when it is heated at temperatures above $85^{\circ} \mathrm{C}$ (Jovanović et al., 2005). Coagulation of milk casein by rennet produced the so called sweet whey, while that produced by lactic acid is called acid whey (Panesar et al., 2007). Whey constitutes high values of lactose, proteins, vitamins and minerals. The average content of whey dry residue is: $70 \%$ lactose, $14 \%$ proteins, $9 \%$ minerals, 4\% fats and 3\% lactic acid (Blažić et al., 2017). The protein bioactive component glycomacropeptide (a milk-protein-derived peptide) comprises $15-20 \%$ of proteins which is a rich source of branched-chain amino acids (leucine, isoleucine, and valine), essential amino acids (cysteine) and peptides as well, which is likely the reason that it is highly effective at promoting protein synthesis (Børsheim et al., 2002; Hulmi et al. 2010). Cysteine amino acid, a precursor of glutathione, the non-enzymatic thiol 518 
Journal of Environmental Sciences (JES)

Faculty of Graduate Studies and Environmental Research, Ain Shams University

Mansour et al.

antioxidant plays key role in reducing oxidative stress, regulating cellular processes, imbalance of which can trigger diseases (Trachootham et al., 2008; Forman et al., 2009; Seidkhani-Nahal et al., 2019).The high nutritional value of whey cheese target towards the generation of value-added products for food industries (Lappa et al., 2019).

Oat (Avena sativa L) (common oat) is a cereal grain belongs to the Poaceae family and is the most important among the cultivated oats. It is suitable for human consumption and is a nutrient-rich food contains high amounts of valuable nutrients such as soluble fibers, proteins, unsaturated fatty acids, vitamins, a number of important minerals, $\beta$-glucan, a mixedlinkage polysaccharide, which forms an important part of oat dietary fiber, and also contains various other phytoconstituents like flavonoids (Singh et al., 2013; Nałęcz et al., 2017). The dietary fiber complex showed antioxidant and antiinflammatory activities in vitro and in vivo studies (Chu et al., 2013; Yang et al., 2014; Marmouzi et al., 2017).

Worldwide, for the past few years the demand for bakery products like biscuits and crackers are increasing and such ready-to-eat, inexpensive and convenient processed food products which are widely consumed. Different types of biscuits and crackers contain high contents of fat, sugar and calories, but they are low in fiber, vitamins, and minerals. Thus, they do not correspond to the rules of a healthy diet (Karklina et al., 2012; Park et al., 2015). 
Journal of Environmental Sciences (JES)

Faculty of Graduate Studies and Environmental Research, Ain Shams University

Mansour et al.

The development of a commercially viable biscuit and crackers attractive to children and adults that will have a significant reduction in fat and sugar, with fewer calories and contain nutrients like whey and cereals designed to reduce the risk of diseases are highly desirable (Boobier et al., 2006; Kaur et al., 2014; Marques et al., 2016).

Therefore the aim of this study was designed to investigate the proximate composition of the Sensory attributes related to cheese whey (food processing wastes) and oat whole grain powder in the form of functional bakery products (biscuit and cracker) formulates as well as evaluation for their best ratio effect on obese rat model induced by high fat diet through the effect on the body weight gain and the lipid profile.

\section{MATERIALS AND METHODS}

\section{Materials:}

Sweet whey cheese and whole grain oat were obtained in November 2018 from Food and Technology Research Institute, Agriculture Research Center, Giza. Egypt. The whole oat grains were blended in a blender until have turned into a soft powder. While, Corn oil, margarine, sugar, baking powder, salt and yeast were obtained from local market. Whereas, commercial kits used for determining total cholesterol, triglycerides, high-density lipoprotein cholesterol (HDL-C) were purchased from Biodiagnostic Co. Dokki, Egypt. 
Animals: Male Albino Wistar rats with an average weight of $130 \pm 10 \mathrm{~g}$ were obtained in January 2019 from laboratory Animal Breeding of National Organization of Drug Control and Research (NODCAR), Giza, Egypt.

Preparation of biscuits formulates: Biscuit samples were processed from dough containing $10 \%$ whole oat as substituting level for wheat flour and containing whey cheese by blending ratio as shown in Table (1) based on the standard method according to Manley, (2001).

Table (1): Biscuit formulas

\begin{tabular}{|c|c|c|c|c|c|}
\hline \multirow{2}{*}{ Ingredients } & \multicolumn{5}{|c|}{ Biscuit blends } \\
\cline { 2 - 6 } & $\mathbf{B}_{\mathbf{0}}$ & $\mathbf{B}_{\mathbf{1}}$ & $\mathbf{B}_{\mathbf{2}}$ & $\mathbf{B}_{\mathbf{3}}$ & $\mathbf{B}_{\mathbf{4}}$ \\
\hline \hline Wheat flour (g) & 200 & 180 & 180 & 180 & 180 \\
\hline Whole oat (g) & 0 & 20 & 20 & 20 & 20 \\
\hline Margarine (g) & 50 & 45 & 40 & 35 & 30 \\
\hline Sugar (g) & 60 & 60 & 60 & 60 & 60 \\
\hline Baking powder (g) & 2.5 & 2.5 & 2.5 & 2.5 & 2.5 \\
\hline Salt (g) & 1.5 & 1.5 & 1.5 & 1.5 & 1.5 \\
\hline Whey cheese (ml) & 0 & 10 & 20 & 30 & 40 \\
\hline Water (ml) & 40 & 30 & 20 & 10 & 0 \\
\hline
\end{tabular}

$\mathrm{B}_{0}$ : control Biscuits; $\mathrm{B}_{1}, \mathrm{~B}_{2}, \mathrm{~B}_{3} \& \mathrm{~B}_{4}$ : Biscuits formula with $10 \%$ Whole Oat of Wheat flour and whey cheese by blending ratio.

Preparation of crackers formulates: The dough of crackers prepared based on the standard method according to Manley, (2001) by mixing wheat flour with $10 \%$ whole oat as substituting levels, margarine, yeast, baking powder, salt, water and whey cheese by blending ratio, as shown in Table (2). 
Table (2): Crackers formulas

\begin{tabular}{|c|c|c|c|c|c|}
\hline \multirow{2}{*}{ Ingredients } & \multicolumn{5}{|c|}{ Cracker blends } \\
\cline { 2 - 6 } & $\mathbf{C}_{\mathbf{0}}$ & $\mathbf{C}_{\mathbf{1}}$ & $\mathbf{C}_{\mathbf{2}}$ & $\mathbf{C}_{\mathbf{3}}$ & $\mathbf{C}_{\mathbf{4}}$ \\
\hline \hline Wheat flour $(\mathrm{g})$ & 100 & 90 & 90 & 90 & 90 \\
\hline Whole oat $(\mathrm{g})$ & 0 & 10 & 10 & 10 & 10 \\
\hline Margarine $(\mathrm{g})$ & 20 & 18 & 16 & 14 & 12 \\
\hline Yeast $(\mathrm{g})$ & 1 & 1 & 1 & 1 & 1 \\
\hline Salt $(\mathrm{g})$ & 1.5 & 1.5 & 1.5 & 1.5 & 1.5 \\
\hline Baking powder $(\mathrm{g})$ & 1.25 & 1.25 & 1.25 & 1.25 & 1.25 \\
\hline Whey cheese (ml) & 0 & 32.5 & 65 & 97.5 & 130 \\
\hline Water (ml) & 130 & 97.5 & 65 & 32.5 & 0 \\
\hline
\end{tabular}

$\mathrm{C}_{0}$ : control Crackers; $\mathrm{C}_{1}, \mathrm{C}_{2}, \mathrm{C}_{3} \& \mathrm{C}_{4}$ : Crackers formula with $10 \%$ Whole Oat of Wheat flour and Whey cheese by blending ratio

\section{Methods of analysis}

Proximate chemical analysis for biscuits and crackers: All the proximate analysis including; moisture, protein, fat, crude fibers, carbohydrates and ash in biscuits and crackers formula were determined according to the methods of AOAC, (2012).

Sensory attributes for biscuits and crackers: The sensory characteristics of the final product of biscuits and crackers were evaluated according to Watts et al., (1989). Ten panelists from the staff members of National Organization of Drug Control and Research (NODCAR), were chosen to evaluate the products. The panelists were asked to score appearance, surface color, taste, texture, aroma and overall acceptability each on a scale of 1(extremely poor) to 10 (excellent). 
Biological experiment design: The experiment was conducted on forty eight male Albino Wistar rats; they were housed in special cages under controlled conditions. The animals were fed on basal diet according to AIN-93 guidelines (Reeves et al., 1993) and were provided with water ad-libitum during the experimental period.

This study aimed to compare the effect of the eight different types of diets. After feeding on basal diet for 7 days (adaptation period), six rats were kept as a control which fed basal diet during the experiment period G1 (negative control). The other groups (from G2 to G8) were fed with high-fat diet; HFD (basal diet containing 10\% animal fat); the compositions of these diets are shown in Table (3). All groups of rats (6 rats each) were fed the experimental diets for 60 days as follows:

- Group (1) rats were fed on a basal diet (negative control).

- Group (2) rats were fed on HFD (positive control).

- Group (3) rats were fed on HFD + control Biscuit.

- Group (4) rats were fed on HFD + low calorie Biscuit formula three.

- Group (5) rats were fed on HFD + low calorie Biscuit formula four.

- Group (6) rats were fed on HFD + control crackers.

- Group (7) rats were fed on HFD + low calorie crackers formula three.

- Group (8) rats were fed on HFD + low calorie crackers formula four. 
Table (3): Feed composition of rat groups (\%)

\begin{tabular}{|c|c|c|c|c|c|c|c|c|}
\hline $\begin{array}{c}\text { Groups } \\
\text { Composition \% }\end{array}$ & $\mathbf{1}$ & $\mathbf{2}$ & $\mathbf{3}$ & $\mathbf{4}$ & $\mathbf{5}$ & $\mathbf{6}$ & $\mathbf{7}$ & $\mathbf{8}$ \\
\hline \hline Casein & 15 & 15 & 15 & 15 & 15 & 15 & 15 & 15 \\
\hline Corn oil & 10 & 5 & 5 & 5 & 5 & 5 & 5 & 5 \\
\hline Animal Fats & - & 10 & 10 & 10 & 10 & 10 & 10 & 10 \\
\hline Cellulose & 5 & 5 & 5 & 5 & 5 & 5 & 5 & 5 \\
\hline Salt mix. & 4 & 4 & 4 & 4 & 4 & 4 & 4 & 4 \\
\hline Vitamin mix. & 1 & 1 & 1 & 1 & 1 & 1 & 1 & 1 \\
\hline Starch & 65 & 60 & 45 & 45 & 45 & 45 & 45 & 45 \\
\hline Biscuits powder & - & - & 15 & 15 & 15 & - & - & - \\
\hline Crackers powder & - & - & - & - & - & 15 & 15 & 15 \\
\hline
\end{tabular}

The changes in body weight were recorded weekly, blood samples were also taken from the retro-orbital plexus of the eyes from all rats of each group at the end of the experiment; the abdominal fat was excised immediately after bleeding for histopathological examination. Serum was obtained from blood samples by centrifugation at $1500 \mathrm{rpm}$ for $15 \mathrm{~min}$ at an ambient temperature for analysis.

Biochemical investigation: Enzymatic determination of cholesterol was carried out according to Allain et al.,(1974). Fully enzymatic determination of total triglycerides in serum was measured colorimetrically at $546 \mathrm{~nm}$, according to Fossati and Prencipe (1982). The HDL was determined according to the method of Lopes- Virella (1977). While, the low-density lipoproteins (LDL-c) were calculated using Friedewald formula (Friedewald et al., 1972) as follows:

LDL-cholesterol $=$ Total cholesterol $-($ HDL-cholesterol $)-($ Triglycerides $/ 5)$ 
Journal of Environmental Sciences (JES)

Faculty of Graduate Studies and Environmental Research, Ain Shams University

Mansour et al.

Histopathological Examination: Autopsy samples were taken from the abdominal fat of the different groups of rats and used for histological examination as described by Banchroft et al, (1996).

Statistical analysis: Descriptive values of data were expressed as the Mean \pm Standard error (SE) and they were analyzed statistically using the one-way analysis of variance (ANOVA) followed by Duncan's test. In all cases $p<0.05$ was used as the criterion of statistical significance by SAS program (SAS, 2003).

\section{RESULTS AND DISCUSSION}

\section{Proximate composition of biscuits and crackers:}

Chemical Composition of Biscuits: Data given in Table (4) indicated the results of proximate composition of biscuits, where the biscuits formula (B4) had the highest moisture (5.13\%), ash (1.76\%) and carbohydrates (33.00\%) and the lowest fat $(16.71 \%)$ contents as well as the lowest calories value (314.43) compared with the other studied of biscuits formulae. In addition, the biscuits formulae (B3) recorded significant increase in total carbohydrate (32.10) when compared with formula (B1). While the protein contents showed no significant differences between the biscuit formulae. These findings are in accordance with those reported by Zaki and Hussien, (2018). 
Journal of Environmental Sciences (JES)

Faculty of Graduate Studies and Environmental Research, Ain Shams University

Mansour et al.

Table (4): Influence of oat and whey cheese addition on proximate composition of biscuits formulas $(\mathrm{g} / 100 \mathrm{~g})$

\begin{tabular}{|c|c|c|c|c|c|}
\hline \multirow{2}{*}{ Analysis } & \multicolumn{5}{|c|}{ Biscuits samples } \\
\hline & $\mathrm{B}_{0}$ & $\mathrm{~B}_{1}$ & $\mathrm{~B}_{2}$ & $\mathrm{~B}_{3}$ & $\mathrm{~B}_{4}$ \\
\hline Moisture & $3.56^{\mathrm{cd}} \pm 0.06$ & $3.91^{b c} \pm 0.05$ & $4.08^{b} \pm 0.08$ & $3.49^{d} \pm 0.22$ & $5.13^{a} \pm 0.06$ \\
\hline Ash & $0.99^{c} \pm 0.01$ & $1.49^{b} \pm 0.03$ & $1.50^{b} \pm 0.01$ & $1.47^{b} \pm 0.01$ & $1.76^{a} \pm 0.02$ \\
\hline Fat & $21.13^{\mathrm{a}} \pm 0.11$ & $20.1^{b} \pm 0.07$ & $19.55^{c} \pm 0.04$ & $19.64^{c} \pm 0.07$ & $16.71^{\mathrm{d}} \pm 0.08$ \\
\hline Protein & $8.0^{\mathrm{a}} \pm 0.01$ & $8.0^{\mathrm{a}} \pm 0.01$ & $8.0^{\mathrm{a}} \pm 0.01$ & $8.0^{\mathrm{a}} \pm 0.01$ & $8.0^{\mathrm{a}} \pm 0.01$ \\
\hline Fiber & $34.63^{b} \pm 0.13$ & $35.73^{\mathrm{a}} \pm 0.44$ & $35.47^{\mathrm{ab}} \pm 0.34$ & $35.3^{\mathrm{ab}} \pm 0.21$ & $35.4^{\mathrm{ab}} \pm 0.15$ \\
\hline Carbohydrate & $31.69^{b c} \pm 0.09$ & $30.78^{c} \pm 0.58$ & $31.4^{b c} \pm 0.39$ & $32.1^{\mathrm{ab}} \pm 0.11 \mathrm{~b}$ & $33.0^{\mathrm{a}} \pm 0.15$ \\
\hline $\begin{array}{c}\text { Caloric } \\
\text { Kcal/100g }\end{array}$ & $348.9^{\mathrm{a}} \pm 0.86$ & $335.9^{b} \pm 1.74$ & $333.6^{b} \pm 1.42$ & $337.13^{b} \pm 0.53$ & $314.43^{c} \pm 0.96$ \\
\hline
\end{tabular}

Data are mean \pm SE, $n=3$, means with the same letter in the same raw are not significantly different at $5 \%$

Chemical Composition of Crackers: As regard to data given in Table (5) indicated the results of proximate composition of crackers, where the crackers formulae (C3 and $\mathrm{C} 4)$ had the highest moisture $(11.52 ; 10.96 \%)$ and ash $(2.40 ; 2.58 \%)$ respectively. Moreover, the lowest fat $(13.89 ; 13.89 \%)$ contents and the lowest calories value (266.99; $273.69 \%)$, respectively, as compared with the control cracker formula. In addition, the protein contents showed no significant differences $(\mathrm{p} \geq 0.05)$ between the crackers formulae. These results are in harmony with those obtained by (El-Batawy et al., 2018) when utilized cheese whey to improve the quality of Egyptian Baladi bread. 
Table (5): Influence of oat and whey cheese addition on proximate composition of crackers formulas $(\mathrm{g} / 100 \mathrm{~g})$

\begin{tabular}{|c|c|c|c|c|c|}
\hline \multirow{2}{*}{ Analysis } & \multicolumn{5}{|c|}{ Crackers samples } \\
\hline & $\mathrm{C}_{\mathbf{0}}$ & $\mathbf{C}_{1}$ & $\mathbf{C}_{2}$ & $\mathbf{C}_{3}$ & $\mathrm{C}_{4}$ \\
\hline Moisture & $5.35^{c} \pm 0.20$ & $7.48^{b} \pm 0.02$ & $10.92^{\mathrm{a}} \pm 0.74$ & $11.52^{\mathrm{a}} \pm 0.10$ & $10.96^{\mathrm{a}} \pm 0.32$ \\
\hline Ash & $1.81^{c} \pm 0.05$ & $2.22^{b} \pm 0.03$ & $2.49^{a} \pm 0.07$ & $2.40^{\mathrm{ab}} \pm 0.06$ & $2.58^{a} \pm 0.09$ \\
\hline Fat & $19.09^{\mathrm{a}} \pm 0.11$ & $17.49^{b} \pm 0.12$ & $17.56^{b} \pm 0.03$ & $13.89^{c} \pm 0.22$ & $13.89^{c} \pm 0.04$ \\
\hline Protein & $10.06^{\mathrm{a}} \pm 0.00$ & $10.06^{a} \pm 0.00$ & $10.06^{a} \pm 0.00$ & $10.06^{a} \pm 0.00$ & $10.1^{\mathrm{a}} \pm 0.01$ \\
\hline Fibers & $37.40^{\mathrm{a}} \pm 0.20$ & $37.33^{a} \pm 0.43$ & $36.5^{a b} \pm 0.57$ & $36.7^{\mathrm{ab}} \pm 0.26$ & $35.4^{b} \pm 0.68$ \\
\hline Carbohydrates & $26.29^{\mathrm{ab}} \pm 0.36$ & $25.43^{b} \pm 0.38$ & $22.47^{c} \pm 0.23$ & $25.43^{b} \pm 0.43$ & $27.1^{\mathrm{a}} \pm 0.48$ \\
\hline $\begin{array}{c}\text { Caloric } \\
\text { Kcal/100g }\end{array}$ & $317.18^{a} \pm 0.42$ & $299.33^{b} \pm 2.25$ & $288.16^{c} \pm 0.66$ & $266.99^{\mathrm{e}} \pm 0.5$ & $273.69^{d} \pm 1.73$ \\
\hline
\end{tabular}

Data are mean $\pm \mathrm{SE}, \mathrm{n}=3$, means with the same letter in the same raw are not significantly different at $5 \%$

\section{Influence of oat and whey cheese addition on the sensory attributes}

biscuits and crackers: The data presented in Tables (6) and (7) showed the results of sensory evaluation in terms of appearance, surface color, texture, taste, aroma and overall acceptability of biscuits and crackers samples supplied by different concentrations of oat and whey cheese, respectively. Data as regard to biscuits formulae showed that addition of oat and whey cheese improved all of the sensory attributes scores without significant $(\mathrm{p} \geq 0.05$ ) different as compared to the control formula. These findings are supported by the observation of Youssef et al., (2016), who reported that highly acceptable biscuits formula could be obtained by incorporating $10 \%$ 
oat powders in the wheat biscuits formulation and oat flour has nutritional value due to its high levels of dietary fibers.

Table (6): Influence of oat and whey cheese addition on biscuits Sensory attributes

\begin{tabular}{|c|c|c|c|c|c|}
\hline \multirow{2}{*}{ Sensory attributes } & \multicolumn{5}{|c|}{ Biscuits samples } \\
\cline { 2 - 6 } & $\mathbf{B}_{\mathbf{0}}$ & $\mathbf{B}_{\mathbf{1}}$ & $\mathbf{B}_{\mathbf{2}}$ & $\mathbf{B}_{\mathbf{3}}$ & $\mathbf{B}_{\mathbf{4}}$ \\
\hline \hline Appearance & $7.70^{\mathrm{a}} \pm 0.30$ & $7.60^{\mathrm{a}} \pm 0.37$ & $8.30^{\mathrm{a}} \pm 0.26$ & $7.40^{\mathrm{a}} \pm 0.43$ & $8.20^{\mathrm{a}} \pm 0.25$ \\
\hline Surface color & $7.30^{\mathrm{a}} \pm 0.37$ & $7.80^{\mathrm{a}} \pm 0.29$ & $7.90^{\mathrm{a}} \pm 0.23$ & $7.70^{\mathrm{a}} \pm 0.40$ & $7.50^{\mathrm{a}} \pm 0.56$ \\
\hline texture & $7.30^{\mathrm{a}} \pm 0.37$ & $7.90^{\mathrm{a}} \pm 0.28$ & $7.50^{\mathrm{a}} \pm 0.31$ & $7.50^{\mathrm{a}} \pm 0.56$ & $7.50^{\mathrm{a}} \pm 0.40$ \\
\hline Taste & $7.50^{\mathrm{a}} \pm 0.48$ & $7.70^{\mathrm{a}} \pm 0.37$ & $7.50^{\mathrm{a}} \pm 0.37$ & $7.90^{\mathrm{a}} \pm 0.31$ & $7.20^{\mathrm{a}} \pm 0.42$ \\
\hline Aroma & $7.50^{\mathrm{a}} \pm 0.48$ & $7.70^{\mathrm{a}} \pm 0.40$ & $7.60^{\mathrm{a}} \pm 0.43$ & $7.60^{\mathrm{a}} \pm 0.50$ & $7.60^{\mathrm{a}} \pm 0.40$ \\
\hline Overall & $7.40^{\mathrm{a}} \pm 0.27$ & $8.00^{\mathrm{a}} \pm 0.42$ & $8.00^{\mathrm{a}} \pm 0.33$ & $8.10^{\mathrm{a}} \pm 0.41$ & $8.10^{\mathrm{a}} \pm 0.23$ \\
\hline
\end{tabular}

Data are mean \pm SE, $n=10$, Different uppercase superscript letters in the same lines represent statistically significant data at $5 \%$.

While, in crackers samples the appearance, texture, taste and the overall acceptability of crackers in formulae three and four showed significant $(p \geq 0.05)$ increase as compared to the results of the control formula of crackers.

The results of the current study are in harmonization with those obtained by a previous study of Swapna and Rao, (2016), who concluded that $25 \%$ of oats replacement of refined wheat flour showed good quality biscuits. Also, muffins incorporated with $10 \%$ oat fibers showed more sensory score than the control as reported by (Bhise and Kaur, 2015). In the same manner substitution of water with whey or permeate in baladi bread formula especially $100 \%$ could be enhance the sensory properties according to (El-Batawy et al., 2018). 
Table (7): Influence of oat and whey cheese addition on crackers Sensory attributes

\begin{tabular}{|c|c|c|c|c|c||}
\hline \multirow{2}{*}{ Sensory attributes } & \multicolumn{5}{|c|}{ Crackers samples } \\
\cline { 2 - 6 } & C0 & C1 & C2 & C3 & C4 \\
\hline \hline Appearance & $7.20 \mathrm{~b} \pm 0.36$ & $8.00 \mathrm{a} \pm 0.21$ & $8.20 \mathrm{a} \pm 0.20$ & $8.20 \mathrm{a} \pm 0.20$ & $8.20 \mathrm{a} \pm 0.25$ \\
\hline Surface color & $7.40 \mathrm{a} \pm 0.37$ & $7.90 \mathrm{a} \pm 0.23$ & $8.10 \mathrm{a} \pm 0.28$ & $8.20 \mathrm{a} \pm 0.20$ & $8.10 \mathrm{a} \pm 0.23$ \\
\hline texture & $6.50 \mathrm{~b} \pm 0.40$ & $7.80 \mathrm{a} \pm 0.36$ & $7.20 \mathrm{ab} \pm 0.36$ & $7.70 \mathrm{a} \pm 0.30$ & $7.60 \mathrm{ab} \pm 0.43$ \\
\hline Taste & $6.50 \mathrm{~b} \pm 0.40$ & $7.70 \mathrm{a} \pm 0.26$ & $7.50 \mathrm{a} \pm 0.43$ & $8.10 \mathrm{a} \pm 0.28$ & $7.90 \mathrm{a} \pm 0.31$ \\
\hline Aroma & $7.40 \mathrm{a} \pm 0.40$ & $7.70 \mathrm{a} \pm 0.33$ & $7.80 \mathrm{a} \pm 0.39$ & $8.30 \mathrm{a} \pm 0.26$ & $7.80 \mathrm{a} \pm 0.29$ \\
\hline Overall & $7.20 \mathrm{~b} \pm 0.36$ & $7.80 \mathrm{ab} \pm 0.29$ & $7.90 \mathrm{ab} \pm 0.31$ & $8.40 \mathrm{a} \pm 0.27$ & $8.20 \mathrm{a} \pm 0.20$ \\
\hline
\end{tabular}

Data are mean \pm SE, $n=10$, Different uppercase superscript letters in the same lines represent statistically significant data at $5 \%$.

\section{Biological evaluation:}

Growth rate in rats: The effect of whey cheese and oat whole-grain powder in form of normal or low calorie biscuits and crackers formula treatment groups on some growth parameters in rats fed on high fat diet are presented in (Table 8). As shown, all groups had similar body weight at the beginning of the experiment $(p \geq 0.05)$. The lowest final body weight and weight gain was recorded for the groups five and six (13.0 and $7.3 \%$ less than the positive control, $\mathrm{p} \geq 0.05$ respectively). Also other treatment groups recorded slight decrease on weight gain observed in groups three and seven. Meanwhile, an increment was noticed increase in weight gain in groups four and eight but not significant with positive control group. These observations are agreed with Bais et al., (2014; Hong et al., 2015). 
The present study provide that feeding on high fat diet for 60 days was in line with Peng et al., (2013), who found that oat supplementation with HFD by $7.5 \%$ previously showed effective and significant reduction in rats body weight.

Table (8): Growth rate parameters of different experimental rat groups

\begin{tabular}{|c|c|c|c|}
\hline $\begin{array}{c}\text { Parameters } \\
\text { Groups }\end{array}$ & $\begin{array}{c}\text { Initial weight } \\
(\mathbf{g})\end{array}$ & $\begin{array}{c}\text { Final weight } \\
(\mathbf{g})\end{array}$ & $\begin{array}{c}\text { weight gain } \\
(\mathbf{g})^{*}\end{array}$ \\
\hline 1 & $140.0^{\mathrm{a}} \pm 4.47$ & $262.0^{\mathrm{b}} \pm 9.70$ & $122.0 \pm 9.70$ \\
\hline 2 & $142.0^{\mathrm{a}} \pm 3.74$ & $300.0^{\mathrm{a}} \pm 11.40$ & $158.0^{\mathrm{a}} \pm 8.00$ \\
\hline 3 & $138.0^{\mathrm{a}} \pm 3.74$ & $288.0^{\mathrm{ab}} \pm 8.00$ & $150.0 \pm 8.37$ \\
\hline 4 & $142.0^{\mathrm{a}} \pm 3.74$ & $310.0^{\mathrm{a}} \pm 8.94$ & $168.0^{\mathrm{a}} \pm 8.60$ \\
\hline 5 & $138.0^{\mathrm{a}} \pm 3.74$ & $260.0^{\mathrm{b}} \pm 12.65$ & $122.0^{\mathrm{bd}} \pm 9.70$ \\
\hline 6 & $140.0^{\mathrm{a}} \pm 4.47$ & $278.0^{\mathrm{ab}} \pm 8.60$ & $138.0^{\mathrm{d}} \pm 5.83$ \\
\hline 7 & $134.0^{\mathrm{a}} \pm 6.00$ & $286.0^{\mathrm{ab}} \pm 13.27$ & $152.0^{\mathrm{ab}} \pm 11.58$ \\
\hline 8 & $138.0^{\mathrm{a}} \pm 5.83$ & $310.0^{\mathrm{a}} \pm 10.49$ & $172.0^{\mathrm{aef}} \pm 15.94$ \\
\hline
\end{tabular}

Data are mean \pm SE, $n=5$, Different uppercase letters in the same column represent statistically significant data at $5 \%$. Whereas; 1: Normal control group; 2: HFD group; 3: HFD + control Biscuit group; 4: HFD + low calorie Biscuit formula three group; 5: HFD + low calorie Biscuit formula four group; 6: HFD + control cracker group; 7: HFD + low calorie cracker formula three group; 8: HFD + low calorie cracker formula four group. $*$ Data in weight gain column represented significant data at 5\% by superscripts (a) against group (1), (b) against group (2), (c) against group (3), (d) against group (4), (e) against group (5) and (f) against group (8).

Lipid profiles of different groups: Regarding serum lipids, results in Table (9) ascertained that there were significant differences among all treatments in the rats' serum lipid profiles ( $\mathrm{p} \geq 0.05$ ). The whey cheese and oat whole-grain 
powder in form of normal or low calorie biscuits and crackers formula treatment groups exhibited significantly decreased serum total cholesterol, triglycerides and LDL-cholesterol levels. While, elevate the HDL-cholesterol levels in comparing the rat group fed on high fat diet only. This trend has also been reported by Wronkowska et al, (2018) who demonstrated that acid whey supplementation to rats resulted significant decrease in triglycerides.

Table (9): Lipid profiles of different rat groups at the End of experimental period

\begin{tabular}{|c|c|c|c|c|}
\hline $\begin{array}{l}\text { Parameters } \\
\text { Groups }\end{array}$ & $\begin{array}{c}\text { T. Cholesterol } \\
(\mathrm{mg} / \mathrm{dl})\end{array}$ & $\begin{array}{c}\text { Triglycerides } \\
(\mathrm{mg} / \mathrm{dl})\end{array}$ & $\begin{array}{c}\text { HDL } \\
(\mathbf{m g} / \mathbf{d l})\end{array}$ & $\begin{array}{c}\text { LDL } \\
(\mathbf{m g} / \mathrm{dl})\end{array}$ \\
\hline 1 & $121.53^{\mathrm{cd}} \pm 24.67$ & $126.37^{c d} \pm 32.62$ & $46.85^{\mathrm{ab}} \pm 8.82$ & $49.40^{c} \pm 13.47$ \\
\hline 2 & $266.38^{a} \pm 10.48$ & $306.77^{\mathrm{a}} \pm 24.31$ & $21.20^{b} \pm 2.65$ & $183.83^{a} \pm 8.93$ \\
\hline 3 & $164.77^{\mathrm{c}} \pm 25.40$ & $240.00^{a b} \pm 42.52$ & $52.44^{a} \pm 4.82$ & $64.33^{c} \pm 13.82$ \\
\hline 4 & $161.27^{c} \pm 9.61$ & $44.58^{\mathrm{e}} \pm 7.12$ & $73.53^{a} \pm 9.16$ & $78.83^{\mathrm{bc}} \pm 6.20$ \\
\hline 5 & $105.28^{d} \pm 19.05$ & $93.14^{\mathrm{de}} \pm 14.28$ & $47.42^{a b} \pm 3.18$ & $39.23^{c} \pm 16.91$ \\
\hline 6 & $215.32^{b} \pm 16.00$ & $189.55^{b c} \pm 18.52$ & $69.31^{a} \pm 16.72$ & $108.10^{b} \pm 18.59$ \\
\hline 7 & $130.30^{\text {cd }} \pm 16.14$ & $105.49^{\text {de }} \pm 9.23$ & $68.53^{a} \pm 14.10$ & $40.67^{c} \pm 9.85$ \\
\hline 8 & $151.57^{\mathrm{cd}} \pm 6.81$ & $82.79^{\mathrm{de}} \pm 12.81$ & $61.07^{a} \pm 5.62$ & $73.95^{\mathrm{bc}} \pm 1.96$ \\
\hline
\end{tabular}

Data are mean \pm SE, $n=5$, Different uppercase letters in the same column represent statistically significant data at 5\%. Whereas; 1: Normal control group; 2: HFD group; 3: HFD + control Biscuit group; 4: HFD + low calorie Biscuit formula three group; 5: HFD + low calorie Biscuit formula four group; 6: HFD + control cracker group; 7: HFD + low calorie cracker formula three group; 8: HFD + low calorie cracker formula four group.

Histopathological investigation: Abdominal fat was evaluated by histopathological alterations finding in Micrographs (from A to $\mathrm{H}$ ). The 
Journal of Environmental Sciences (JES)

Faculty of Graduate Studies and Environmental Research, Ain Shams University

Mansour et al.

normal histological structure of the adipose tissue with hexagonal shaped adipocytes and peripheral flattened nucleus were recorded in the normal control group; (Micrograph, A). There was congestion in the blood vessels between the lobules were noticed in the positive control group fed on high fat diet (HFD); (Micrograph, B). The abdominal fat sections obtained from animals treated with HFD plus control biscuit and low calorie biscuit formula three showed no histopathological alteration as recorded in (Micrograph, C \& D). While, the abdominal fat sections obtained from animals treated with HFD plus low calorie biscuit formula four observed congestion in the blood vessels between the cells (Micrograph E). The abdominal fat sections obtained from animals treated with HFD plus all treatment of crackers showed no histopathological alteration as recorded in (Micrograph, F;G\&H).

The histopathological changes in treated groups with normal or low calorie formula of biscuits and crackers except for low calorie biscuit formula four as compared to that induced with high fat diet alone indicated marked protective effects of whey cheese and oat addition against weight gain. These results were previously supported by Althwab et al., (2020), who reported that whey supplementation efficacy in preventing overweight and obesity by lowering weight gain and serum levels of lipids.

\section{CONCLUSION}

As appeared from the aforementioned data, treatment fortified with whey cheese and whole-grain oat in form of low calorie biscuits and crackers formula can be used as effective food supplements for reducing overweight 
Journal of Environmental Sciences (JES)

Faculty of Graduate Studies and Environmental Research, Ain Shams University

Mansour et al.

and obesity in rats by lowering weight gain, adipocyte histopathological alteration and serum levels of lipids profile; confirmed protective ability of these treatments.

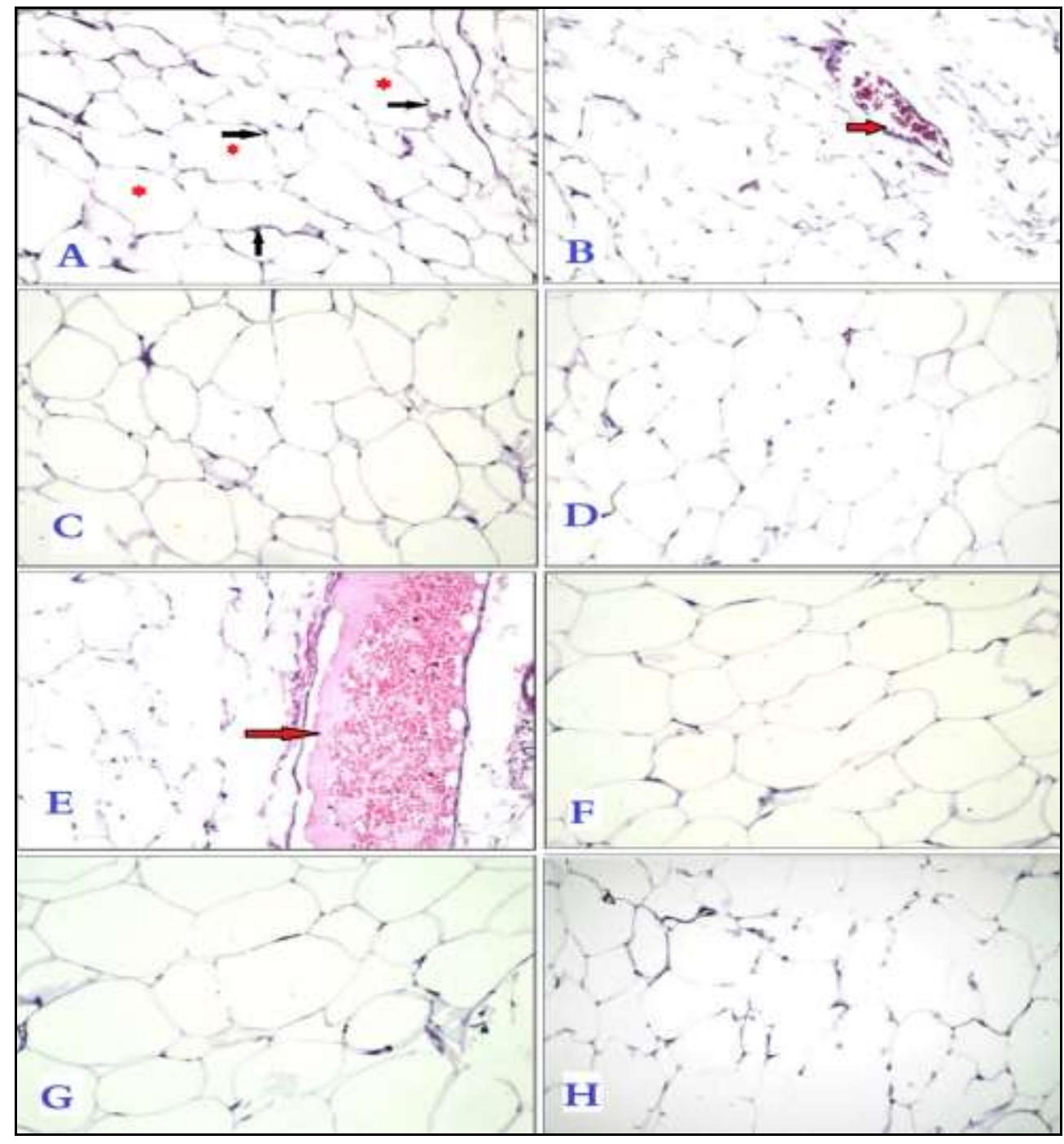

Vol. (50); Iss. (11); No. (7); Nov. 2021

ISSN $1110-0826$

ONLINE ISSN 2636 - 3178 
Journal of Environmental Sciences (JES)

Faculty of Graduate Studies and Environmental Research, Ain Shams University

Mansour et al.

Figures (A- H): Represent photomicrographs of abdominal fat tissue sections of rat groups. (A), is the micrograph of the negative control rat shows normal histological structure of the adipocytes (red star) with hexagonal shape and peripheral flattened nucleus (black arrow). (B) is the micrograph of the HFD group (positive control) rat shows congestion in the blood vessels between the lobules (red arrow). (C) micrograph represents the HFD + control Biscuit group and (D) represents the HFD + low calorie Biscuit formula three group, both show no histopathological alterations. (E), is the micrograph of the HFD + low calorie Biscuit formula four group shows congestion in the blood vessels between the cells (red arrow). While (F), micrograph of the HFD + control crackers group, $(\mathrm{G})$, micrograph of the HFD + low calorie crackers formula three group and $(\mathrm{H})$ micrograph of the HFD + low calorie crackers formula four group show no histopathological alteration. (H \& E, 40x).

\section{REFERENCES}

Allain, C. C.; Poon, L. S.; Chan, C. S. G.; Richmond, W. and Fu, P. C. (1974): Enzymatic determination of total serum cholesterol. Clinical Chemistry, 20(4), 470-475. https://doi.org/10.1093/clinchem/20.4.470

Althwab, S. A.; Alsudais, M. A.; Mousa, H. M.; Ashoush, I. S. and Hamad, E. M. (2020): Reduction of lipid profile and adipocyte size in rats fed on high-fat diet using camel milk and whey protein mixture. Food Science and Technology Research, 26(4), 527-534. https://doi.org/10.3136/FSTR.26.527 
Journal of Environmental Sciences (JES)

Faculty of Graduate Studies and Environmental Research, Ain Shams University

Mansour et al.

AOAC (2012): Official Methods of Analysis of the Association of Official Analytical Chemistry (A.O.A.C.) International, $19^{\text {th }}$ ed., Gaithersburg, Maryland, USA.

ASN (American Society for Nutrition) (1998): Clinical guidelines on the identification, evaluation, and treatment of overweight and obesity in adults: Executive summary. Expert panel on the identification, evaluation, and treatment of overweight in adults. The American Journal of Clinical Nutrition. 68, 899-917. https://doi.org/10.1093/ajcn/68.4.899

Bais, S.; Singh, G.S. and Sharma, R. (2014): Antiobesity and hypolipidemic activity of Moringa oleifera leaves against high fat diet-induced obesity in rats. Advances in Biology. Article ID 162914, 9 pages. http://dx.doi.org/10.1155/2014/162914.

Banchroft, J. D.; Stevens, A. and Turner, D. R. (1996): Theory and practice of histological techniques Fourth ed. Churchil Livingstone. New York, London, San Fr. Tokyo.

Bhise, S. and Kaur, A. (2015): Fortifying muffins with psyllium husk fiber, oat fiber and barley fiber to improve quality and shelf life. Carpathian Journal of Food Science and Technology, 7(2), 5-16.

Blažić, M.; Pavić, K.; Zavadlav, S. and Marčac, N. (2017): The impact of traditional cheeses and whey on health. Croatian Journal of Food Science and Technology, 9(2), 198-203. https://doi.org/10.17508/cjfst.2017.9.2.11

Boobier, W.; Baker, J. and Davies, B. (2006): Development of a healthy biscuit: An alternative approach to biscuit manufacture. Nutrition Journal 5(1): 1-7. https://doi.org/10.1186/1475-2891-5-7

Børsheim, E.; Tipton, K. D.; Wolf, S. E. and Wolfe, R. R. (2002): Essential amino acids and muscle protein recovery from resistance exercise. American Journal of Physiology - Endocrinology and Metabolism, 283(4). 648-657. https://doi.org/10.1152/ajpendo.00466.2001 
Chu, Y. F.; Wise, M. L.; Gulvady, A. A.; Chang, T.; Kendra, D. F.; JanWillem Van Klinken, B.; Shi, Y. and O'Shea, M. (2013): In vitro antioxidant capacity and anti-inflammatory activity of seven common oats. Food Chemistry, 139(1-4), 426-431. https://doi.org/10.1016/j.foodchem.2013.01.104

El-Batawy, O.I.; Mahdy, S. M. and Abo El-Naga, M. Y. (2018): Utilization of cheese whey and UF milk permeate in manufacture of Egyptian Baladi bread. Alexandria Journal of Food Science and Technology, 15(1), 9-22. https://doi.org/10.21608/ajfs.2018.16345

Forman, H. J.; Zhang, H. and Rinna, A. (2009): Glutathione: overview of its protective roles, measurement, and biosynthesis. Molecular Aspects of Medicine, 30(1-2), 1-12. https://doi.org/10.1016/j.mam.2008.08.006

Fossati, P. and Prencipe, L. (1982): Serum triglycerides determined colorimetrically with an enzyme that produces hydrogen peroxide. Clinical Chemistry, 28(10), 2077-2080. https://doi.org/10.1093/clinchem/28.10.2077

Friedewald, W. T.; Levy, R. I. and Fredrison, D. S. (1972): Estimation of the concentration of low-density lipoprotein cholesterol in plasma, without use of the preparative ultracentrifuge. Clinical Chemistry, 18(6), 499-502. https://doi.org/10.1093/clinchem/18.6.499

Hong, S. M.; Chung, E. C. and Kim, C. H. (2015): Anti-obesity Effect of Fermented Whey Beverage using Lactic Acid Bacteria in Dietinduced Obese Rats. Korean Journal for Food Science of Animal Resources, $35 \quad$ (5), 653-659. https://doi.org/10.5851/kosfa.2015.35.5.653

Hruby, A. and Hu, F. B. (2015): The Epidemiology of Obesity: A Big Picture. PharmacoEconomics, 33(7), 673-689. https://doi.org/10.1007/s40273-014-0243-x 
Hulmi, J. J.; Lockwood, C. M. and Stout, J. R. (2010): Effect of protein/essential amino acids and resistance training on skeletal muscle hypertrophy: A case for whey protein. Nutrition and Metabolism. 7(51)1-11. https://doi.org/10.1186/1743-7075-7-51

Jovanović, S.; Barać M. and Maćej O. (2005): Whey proteins-properties and possibility of application. Mljekarstvo: časopis za unaprjeđenje proizvodnje i prerade mlijeka 55(3): 215-233.

Karklina, D.; Gedrovica, I.; Reca, M. and Kronberga, M. (2012): Production of biscuits with higher nutritional value. Proceedings of the Latvian Academy of Sciences, Section B: Natural, Exact, and Applied Sciences, 66(3), 113-116. https://doi.org/10.2478/v10046-012-0005-0

Kaur, K. D.; Jha, A.; Sabikhi, L. and Singh, A. K. (2014): Significance of coarse cereals in health and nutrition: A review. Journal of Food Science and Technology, 51(8), 1429-1441. https://doi.org/10.1007/s13197-011-0612-9

Lappa, I. K.; Papadaki, A.; Kachrimanidou, V.; Terpou, A.; Koulougliotis, D.; Eriotou, E. and Kopsahelis, N. (2019): Cheese whey processing: Integrated biorefinery concepts and emerging food applications. Foods. MDPI Multidisciplinary Digital Publishing Institute. https://doi.org/10.3390/foods 8080347

Lopes Virella, M. F.; Stone, P.; Ellis, S. and Colwell, J. A. (1977): Cholesterol determination in high density lipoproteins separated by three different methods. Clinical Chemistry, 23(5), 882-884. https://doi.org/10.1093/clinchem/23.5.882

Manley, D. (2001): Biscuit, cracker and cookie recipes for the food industry. Woodhead Publishing Limited. https://doi.org/10.1533/9781855736269 
Marmouzi, I.; Karym, E. M.; Saidi, N.; Meddah, B.; Kharbach, M.; Masrar, A.; Bouabdellah, M.; Chabraoui, L.; El Allali, K. and Cherrah, Y.; Faouzi, M. E. A. (2017): In vitro and in vivo antioxidant and antihyperglycemic activities of moroccan oat cultivars. Antioxidants, 6(4). 1-20. https://doi.org/10.3390/antiox6040102

Marques, G. de A.; São José, J. F. B. de; Silva, D. A. and Silva, E. M. M. da. (2016): Whey protein as a substitute for wheat in the development of no added sugar cookies. LWT - Food Science and Technology, 67, 118-126. https://doi.org/10.1016/j.1wt.2015.11.044

Nałęcz, D.; Dziuba, M. and Szerszunowicz, I. (2017): Isolation of oat (Avena sativa L.) total proteins and their prolamin fractions for $2 \mathrm{D}$ electrophoresis. In Methods in Molecular Biology (Vol. 1536, pp. 225-234). Humana Press Inc. https://doi.org/10.1007/978-1-49396682-0_16

Panesar, P. S.; Kennedy, J. F.; Gandhi, D. N. and Bunko, K. (2007): Bioutilisation of whey for lactic acid production. Food Chemistry. 105(1): 1-14. https://doi.org/10.1016/j.foodchem.2007.03.035

Park, J.; Choi, I. and Kim, Y. (2015): Cookies formulated from fresh okara using starch, soy flour and hydroxypropyl methylcellulose have high quality and nutritional value. LWT - Food Science and Technology, 63(1), 660-666. https://doi.org/10.1016/j.lwt.2015.03.110

Peng, C.-H.; Chang, H.-C.; Yang, M.-Y.; Huang, C.-N.; Wang, S.-J. and Wang, C.-J. (2013): Oat attenuate non-alcoholic fatty liver and obesity via inhibiting lipogenesis in high fat-fed rat. Journal of Functional Foods 5, 53-61. https://doi.org/https://doi.org/10.1016/j.jff.2012.08.003 
Journal of Environmental Sciences (JES)

Faculty of Graduate Studies and Environmental Research, Ain Shams University

Mansour et al.

Reeves, P. G.; Nielsen, F. H. and Fahey, G. C. Jr. (1993): AIN-93 purified diets for laboratory rodents: final report of the American Institute of Nutrition ad hoc writing committee on the reformulation of the AIN-76A rodent diet. The Journal of Nutrition, 123(11), 19391951. https://doi.org/10.1093/jn/123.11.1939

SAS (2003): SAS/ Stat Users Guide: Statistics, System for Windows, version 4.10 (release 8.01 TS level 01M0), SAS Inst., Inc. Cary, North Carolina, USA.

Seidkhani-Nahal, A.; Allameh, A. and Soleimani, M. (2019): Antioxidant and reactive oxygen species scavenging properties of cellular albumin in HepG2 cells is mediated by the glutathione redox system. Biotechnology and Applied Biochemistry, 66(2), 163-171. https://doi.org/10.1002/bab.1708

Singh, R.; De, S. and Belkheir, A. (2013): Avena sativa (Oat), A potential neutraceutical and therapeutic agent: An overview. Critical Reviews in Food Science and Nutrition, 53(2), 126-144. https://doi.org/10.1080/10408398.2010.526725

Stenkula, K. G. and Erlanson-Albertsson, C. (2018, August 20): Adipose cell size: Importance in health and disease. American Journal of Physiology - Regulatory Integrative and Comparative Physiology. American Physiological Society. https://doi.org/10.1152/ajpregu.00257.2017

Swapna, K. S. and Rao, K. J. (2016): Studies on effect of oat and cheese incorporation on sensory and textural quality of short-dough type biscuit. Journal of food science and technology, 53(3), 15051514. https://doi.org/10.1007/s13197-015-2014-X

Trachootham, D.; Lu, W.; Ogasawara, M. A.; Nilsa, R. D. and Huang, P. (2008): Redox regulation of cell survival. Antioxidants \& Redox Signaling, $10(8)$ $1343-1374$. https://doi.org/10.1089/ars.2007.1957 
Watts, B. M.; Ylimaki, G. L.; Jeffery, L. E. and Elias, L. G. (1989): Basic sensory methods for food evaluation. Ottawa. The International Development Research Center, pp. 160.

Wronkowska, M.; Juśkiewicz, J.; Zduńczyk, Z.; Warechowski, J.; SoralŚmietana, M. and Jadacka, M. (2018): Effect of high added-value components of acid whey on the nutritional and physiological indices of rats. Journal of Functional Foods, 50, 63-70. https://doi.org/10.1016/j.jff.2018.09.019

Yang, J.; Ou, B.; Wise, M. L. and Chu, Y. (2014): In vitro total antioxidant capacity and anti-inflammatory activity of three common oatderived avenanthramides. Food Chemistry, 160, 338-345. https://doi.org/10.1016/j.foodchem.2014.03.059

Youssef, M. K. E.; Nassar, A. G.; EL-Fishawy, F. A. and Mostafa, M. A. (2016): Assessment of proximate chemical composition and nutritional status of wheat biscuits fortified with oat powder. Assiut Journal of Agricultural Sciences 47, 83-94. https://doi.org/10.21608/ajas.2016.2071

Zaki, H. and Hussien, A. (2018): Chemical, rheological and sensory properties of wheat-oat flour composite cakes and biscuits. Journal of Productivity and Development,, 23, 287-306. https://doi.org/10.21608/jpd.2018.42018 


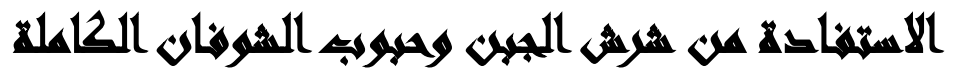

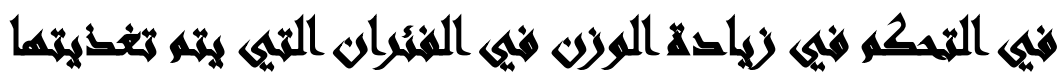

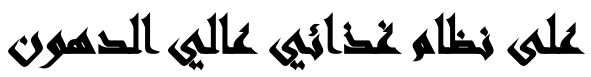
وائل محمد منصور (')- محمد عبد الرزلق النواوي(')- وجيه أحمد المالكي(')

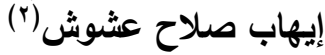

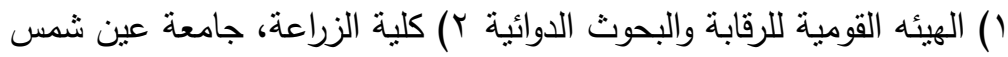

\section{lingaring}

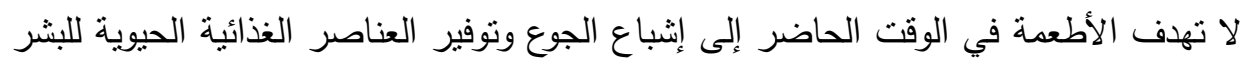

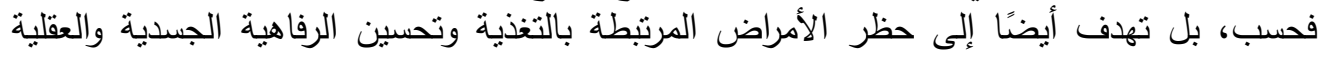

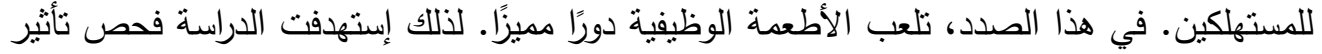

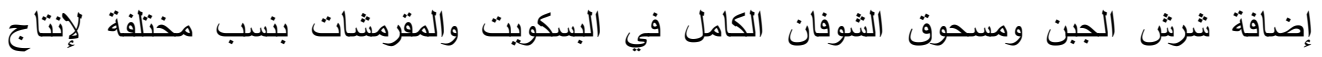

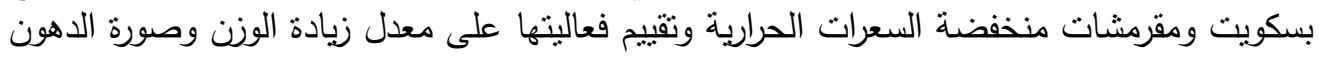

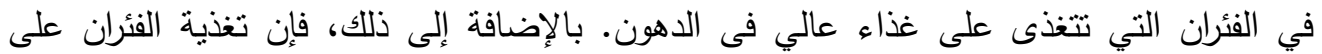

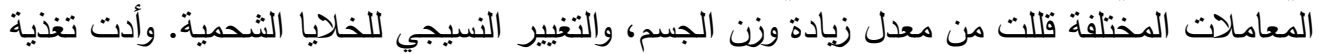

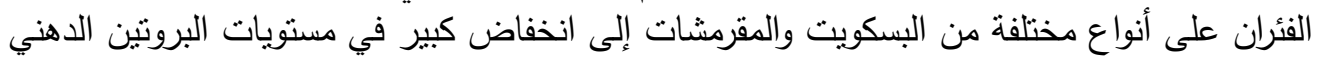

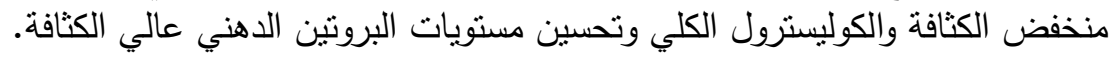

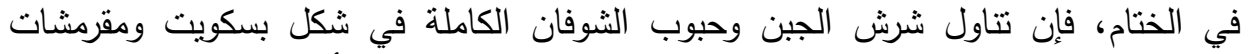

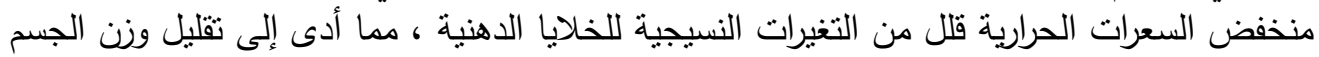
اللفئران. الكلمات الدالة: شرش الجبن، الثوفان، الزيادة فى الوزن، صورة ليبيدات الدم، الفئران. 